\title{
2. Gaining comprehensive AIDS treatment in South Africa: the extraordinary 'ordinary'
}

\author{
STEVEN FRIEDMAN
}

The fight for a comprehensive government response to HIV and AIDS has been one of the more significant sagas of post-apartheid South Africa - and one of the strangest. The Treatment Action Campaign (TAC) is justifiably seen as the clearest evidence thus far that citizen action can change policy in the new South African democracy. The ability of a coalition of activists, opinion-formers and local and international civil society organizations to prompt the government to change a policy on HIV and AIDS which it had energetically defended seemed to confirm that citizen action could exert influence in post-apartheid South Africa.

The campaign to win comprehensive support for people living with AIDS can be judged a success: not only have tens of thousands of lives been saved, but progress in winning support within government created a platform for potential gains. The campaign pressed multinational companies to make medicine available at lower prices or to give up their right to exclusive supply in exchange for a royalty (Friedman and Mottiar 2004). It has also played a role in protecting people living with AIDS from violent victimization where they live. In various ways, the needs of people living with AIDS reached the consciousness of people in a position to do something about them in a manner which would not be conceivable without the campaign.

The campaign defied many routine assumptions of political analysis. Campaigns for policy change are generally needed when governments are divided from campaigners by differences in interest or ideology: the campaign can then be analysed as a process in which campaigners try to pressure or persuade political power-holders to revise their understanding of their interests. By contrast, the campaign for a change in South African government policy on HIV and AIDS was fought between a government and a coalition who were not divided by any noticeable difference of interest or value. The activists who led the fight for a change in policy had not been expecting to campaign against the government at all. Their intended targets were the multinational pharmaceutical companies which were expected to obstruct attempts to secure afford- 
able treatment for people living with the virus. ${ }^{1}$ Since the government had passed a law allowing it to undercut their dominance of the market by importing cheaper medicines (TAC 2001), and since its own constituency is severely affected by the virus, it was expected to ally itself with the campaign for a comprehensive response to AIDS. Instead, it became its prime opponent.

Despite its unusual character, the campaign has many features which help us understand how citizen action might achieve national policy change. This chapter discusses the campaign in the period 1998 to 2007, its achievements and limits, and its implications for a clearer understanding of the obstacles and openings which face attempts by campaigners to alter national policy. ${ }^{2}$ All descriptions of TAC structure and procedures date from 2007 , when the research on which this chapter is based was conducted. At the time of writing, in 2009, the campaign continues. $^{3}$

\section{The Treatment Action Campaign: structure and governance}

Launched in 1998, TAC was a response to the HIV and AIDS epidemic whose impact was becoming apparent: in 2002, 5 million South Africans were believed to be HIV positive (Directorate Health Systems Research 2002). TAC aimed to 'campaign for greater access to treatment for all South Africans, by raising public awareness and understanding about issues surrounding the availability, affordability and use of HIV treatments' (TAC 2007). Its founders were two former anti-apartheid activists, Zackie Achmat (who is HIV positive) and Mark Heywood; they sought to use the techniques developed in the fight against apartheid to press pharmaceutical firms to offer affordable medication to people living with AIDS. ${ }^{4}$

TAC employed a multi-strategy approach to campaigning, using methods ranging from civil disobedience and street demonstrations through action in the courts to measured pamphlets spelling out scientific arguments. It was not only a campaigning organization: it also ran programmes which offer important services to its members, providing treatment and information. It also combined service provision with civil disobedience - in 2002, for example, it imported generics from Brazil, ignoring the patents held by pharmaceutical companies (Nessman 2002).

TAC is a membership organization; during the period of the research, important aspects of its internal structure were unconventional. There was no clear-cut distinction between members and 'supporters', 'volunteers' or 'activists', ${ }^{5}$ although membership - which was free - was 
relevant in the election of office bearers. Members elected the national executive, but social sectors - children, youth, faith-based organizations, healthcare professionals and trade unions - were also represented. ${ }^{6}$ In 2005, membership was said to be around 12,000 (TAC 2005) but activists pointed out that the numbers participating in TAC marches - which they estimated at between 8,000 and 15,000 - indicated an ability to mobilize people well in excess of membership. ${ }^{7}$ Most TAC members were women, which is unsurprising given that women are far more likely to be HIV positive (Department of Health 2002). They also appeared to be active participants, attending meetings in greater numbers than men and being more active in TAC activities. ${ }^{8}$

Despite its unconventional approach to membership, TAC had a formal structure which provided for internal representative democracy. The basic unit was the branch. Each province in which it was active also had a provincial executive committee; its prime decision-making structure was the national executive committee. National leadership was nominated by branches and elected at a national congress every two years, where four national office bearers were also elected.

There was broad agreement within TAC that major strategic decisions were initiated by the national leadership, although some compromise between its view and that of other levels did seem evident. There were tensions between the national leadership and the provinces: 'often there is resistance to national control: national has directed that all the treatment literacy campaigns be run in the same way in all the provinces - but we here in Gauteng [Province] have some ideas of our own and are constantly voicing our need to do things our way'. ${ }^{9}$ These did not become a serious source of conflict. Finances were tightly controlled at the national level, a strategy justified on the grounds that it guards against wastage and corruption.

The fact that the national level took decisions was not in itself a sign that members lacked a say. Provinces and branches were consulted about strategies and tactics, ${ }^{10}$ but over-romantic views of internal democracy within TAC would be inappropriate. There were structural constraints to some expressions of democracy because some of TAC's strategies required technical knowledge which was unavailable to grassroots members lacking formal education. In some cases, concerns for financial probity may also have created constraints to internal democracy. It is almost inevitable that at times a divide emerges between, on the one hand, the small group of national officials whose formal education or political histories or both give them an inbuilt advantage in addressing technical and strategic issues and, on the other, the grass roots. 